\title{
PEER AND SELF ASSESSMENT IN ACCOUNTING EDUCATION (CASE STUDY OF ACCOUNTING EDUCATION IN UPH SURABAYA)
}

\author{
Evelyn Setiawan \\ Universitas Kristen Petra \\ evelyn.setiawan@yahoo.com
}

\begin{abstract}
An accountant is required to have competence to interpret and communicate the results of his/her thinking properly. Such capabilities could be established from the college time through student involvement in peer and self-assessment. This study analyzed the peer and self-assessment done in financial statements analysis class, which held in accounting study program, UPH Surabaya. The result showed that the peer and self assessment can be run effectively when there is an adequate explanation prior to the assessment.
\end{abstract}

Keywords: peer assessment, self assessment

Abstrak: Seorang akuntan dituntut untuk memiliki kompetensi untuk membuat interpretasi dan mengkomunikasikan hasil pemikirannya dengan baik. Kemampuan tersebut dapat dibentuk sejak masa kuliah melalui keterlibatan mahasiswa dalam peer dan self assessment. Penelitian ini menganalisis peer dan self assessment yang dilakukan di kelas analisis laporan keuangan pada program studi akuntansi UPH Surabaya. Hasil penelitian menunjukkan bahwa peer dan self assessment dapat dijalankan dengan efektif ketika terdapat penjelasan yang memadai sebelum penilaian dilakukan.

Kata kunci: peer assessment, self assessment

Saat ini, peran seorang akuntan dalam dunia bisnis tidak hanya sebagai book-keeper saja. The American Institute of Certified Public Accountants (AICPA) menyatakan bahwa seorang akuntan di masa sekarang dan masa mendatang harus memiliki kemampuan untuk menghubungkan data, pengetahuan dan wawasan untuk membuat interpretasi tentang informasi keuangan maupun non keuangan. Para akuntan juga dituntut untuk memiliki kemampuan untuk mengkomunikasikan pemikirannya dengan baik dan memiliki kemampuan interpersonal yang memadai.

Kompetensi yang diharapkan dari seorang akuntan tersebut harus dibentuk sejak pada bangku kuliah. Kerby (2008) mengungkapkan bahwa selama lebih dari dua puluh tahun terakhir, para akuntan profesional telah terpanggil untuk melakukan pengembangan pembelajaran pada mahasiswa akuntansi. Oleh karena itu, para mahasiswa harus dilibatkan secara aktif dalam proses pembelajaran, tidak hanya sekedar menjadi pendengar pasif saja (AECC, 1990).

Salah satu cara untuk meningkatkan keterlibatan mahasiswa dalam proses pembelajaran adalah dengan proses peer dan self assessment. Chaney \& Ingraham (2009) mengungkapkan 
bahwa peer assessment merupakan metode yang efektif untuk meningkatkan kualitas proses belajar mahasiswa. Mahasiswa akan lebih terpacu jika mereka merasa "diawasi" dan "dinilai" oleh teman sejawatnya sendiri. Bahkan hasil penelitian terdahulu juga membuktikan bahwa mahasiwa lebih cenderung mendengarkan komentar dari teman sejawatnya dibanding dengan komentar dari profesornya (Hirsch and Gabriel, 1995). Hancock, Dale-Jones, \& Willey (2013) menyatakan bahwa peer dan self assessment merupakan salah satu cara untuk meningkatkan kemampuan seorang calon akuntan untuk membuat pertimbangan (judgement) dan berkomunikasi secara tertulis (written communication). Sejalan dengan pernyataan tersebut, Rochmiyati (2013) menyebutkan bahwa jika peer assessment dibangun dan diterapkan dengan baik akan dapat meningkatkan kecakapan kognitif dan kecakapan sosial siswa yang mengantarkan seseorang berhasil berinteraksi dengan orang lain dalam kehidupan sehari-hari.

Sekalipun manfaat dan dukungan untuk melakukan peer dan self assessment cukup banyak, namun pada prakteknya, kedua penilaian ini masih jarang dilakukan (Birjandi \& Siyyari, 2010). Hal ini disebabkan karena kurangnya kemampuan para pengajar untuk melakukan penilaian secara akurat dan reliabel.

Penelitian ini bertujuan untuk melihat sejauh mana keakuratan peer assessment yang dilakukan oleh mahasiswa program studi akuntansi, khususnya dalam program studi akuntansi di UPH Surabaya. Proses ini diharapkan dapat meningkatkan keterlibatan mahasiswa dalam proses pembelajaran. Dalam jangka panjang, proses ini akan berdampak pada pembentukan keterampilan interpersonal mahasiswa yang dibutuhkan di dunia kerja.

\section{KAJIAN PUSTAKA}

Peer dan self assessment adalah filosofi dasar dari prinsip pembelajaran aktif (Falchikov dan Goldfinch, 2000). Kedua konsep ini bukan hanya sekedar membagikan rubrik penilaian kepada siswa agar cara penilaian bersifat terbuka dan transparan, namun juga melatih siswa agar dapat bersikap realistis untuk memutuskan berapa nilai yang pantas mereka peroleh sesuai dengan hasil usahanya (Thomas, Martin, \& Pleasant, 2011). Selain itu, dengan menerapkan peer dan self assessment, siswa dapat memperoleh feedback sehingga mereka dapat mengetahui sejauh mana penguasaan materi dan kemampuannya dalam penerapan materi tersebut (Siswaningsih, Dwiyanti, \& Gumilar, 2013).

Thomas, Martin, \& Pleasant (2011) mengutip penelitian Boud \& Falchikov (1989) yang mendefinisikan self assessment sebagai keterlibatan siswa dalam membuat penilaian tentang proses belajarnya sendiri, khususnya tentang pencapaian dan hasil akhir dari proses belajar 
mereka. Dalam peer assessment, siswa akan menilai pekerjaan rekan sejawatnya sendiri, yang meliputi jumlah, tingkatan, nilai, bobot, kualitas, atau kesuksesan pembelajarannya (Topping, 1998). Peer dan self assessment berpotensi memacu siswa untuk meningkatkan prestasi belajarnya.

Self dan peer assessment merupakan bentuk pembelajaran mandiri yang sangat berguna untuk menunjang kesuksesan seorang siswa, baik selama belajar di kampus maupun pada saat menjalani karir profesional (Thomas, Martin, \& Pleasant, 2011). Willey \& Freeman (2006) mengungkapkan manfaat dari peer assessment antara lain sebagai berikut:

1. Memaksa mahasiswa yang bertindak sebagai penilai untuk lebih memahami proses pembelajaran yang terjadi

2. Meningkatkan pemahaman mahasiswa akan pentingnya penilaian

3. Meningkatkan motivasi belajar mahasiswa

4. Membangun keterampilan professional mahasiswa, seperti cara berefleksi dan cara berpikir kritis nantinya.

Hasil penelitian Chaney \& Ingraham (2009) menyatakan bahwa siswa dapat meningkatkan kemampuan mereka untuk melakukan analisis kasus setelah melakukan peer dan self assessment. Kemampuan untuk analisis kasus ini sangat dibutuhkan pada saat mereka bekerja sebagai akuntan profesional nantinya. Peningkatan kemampuan analisis ini disebabkan karena tiga hal, yaitu meningkatnya akuntabilitas siswa ketika mereka merasa bahwa tugas mereka akan dinilai oleh teman mereka sendiri, adanya peningkatan kualitas tugas yang mereka kerjakan setelah mereka dievaluasi oleh teman mereka sendiri, dan peningkatan standar kualitas tugas karena mereka harus mengikuti standar teman mereka yang mungkin lebih tinggi dari standar mereka sendiri.

Menurut Kennedy dalam Rochmiyati (2013), ada beberapa masalah yang dihadapi dalam praktek peer assessment. Siswa bisa saja kurang konsisten dalam melakukan penilaian. Selain itu, ada siswa tertentu yang khawatir akan membuat kesalahan sehingga ia tidak bebas dalam melakukan penilaian. Peer assessment juga memungkinkan timbulnya konflik antar anggota yang berakibat pada menurunnya kerjasama dan kinerja kelompok. Yang terakhir, peer assessment dapat menambah perbedaan peringkat antar siswa.

Karami \& Rezaei (2015) menyatakan bahwa efektifivas peer assessment sangat ditentukan oleh berbagai faktor, seperti perilaku mahasiswa, penguasaan mahasiswa terhadap kriteria penilaian, faktor yang dinilai, dan adanya kemungkinan penilaian yang bias karena faktor pertemanan atau perbedaan gender. Hal ini sejalan dengan pernyataan Landry, Jacobs, \& Newton (2015) bahwa hasil peer assessment tidak dapat diharapkan sepenuhnya positif 
dan konsisten karena penilaian ini berfokus sepenuhnya pada mahasiswa. Ada kemungkinan mahasiswa memberikan penilaian yang jelek pada teman yang kurang mereka sukai, dan sebaliknya memberikan penilaian yang bagus pada teman yang mereka sukai, sekalipun penilaian tersebut kurang sesuai dengan kinerjanya. Oleh karena itu diperlukan penilaian yang berulang-ulang agar hasil yang didapatkan lebih akurat dan kurang lebih sama dengan penilaian yang dilakukan oleh dosen.

Untuk dapat menjalankan peer dan self assessment dengan baik, seorang pendidik perlu menyiapkan silabus yang jelas, yang memuat tujuan pembelajaran dan target yang ditetapkan untuk masing-masing individu (Reese-Durham, 2005). Penilaian dapat dilakukan dengan menggunakan rubrik yang memuat aspek-aspek penting penilaian.

Siswaningsih, Dwiyanti, \& Gumilar (2013) melakukan penelitian tentang Penerapan Peer Assessment dan Self Assessment Pada Tes Formatif Hidrokarbon Untuk Feedback Siswa SMA Kelas X. Dalam penelitian ini dilakukan enam tahapan kegiatan yaitu pemotivasian siswa, pelatihan peer assessment dan self assessment, pelaksanaan tes formatif dan pemberian feedback, pelaksanaan peer assessment, pelaksanaan self assessment dan pemberian feedback, pengkomunikasian hasil, dan pemanfaatan hasil. Pada tahapan pemotivasian, siswa diberi informasi mengenai pengertian, tujuan, manfaat peer assessment dan self assessment, serta keunggulan peer assessment dan self assessment dibandingkan dengan jenis penilaian lain. Tahap pelatihan adalah tahapan saat siswa diberikan penjelasan mengenai teknis pelaksanaan peer assessment dan self assessment.

Lebih jelas, Thomas, Martin, \& Pleasant (2011) menjelaskan tentang tiga strategi yang dapat digunakan untuk meningkatkan kualitas peer dan self assessment, yaitu modelling, scaffolding, and fading. Modelling adalah pendidik yang memberikan contoh cara penilaian dan strategi untuk menjamin realibilitas dan akurasi nilai. Tahap kedua dilakukan dengan membangun skema penilaian yang terstruktur, misalnya dengan membuat rubrik penilaian. Semakin sering siswa melakukan peer dan self assessment, semakin positif pula sikap mereka terhadap sistem penilaian ini. Pada saat itu, pengawasan pendidik semakin lama semakin dikendurkan dan siswa dapat melakukan penilaian tersebut secara independen.

Ada beberapa hal yang dapat menghambat kesuksesan peer dan self assessment. Thomas, Martin, \& Pleasant (2011) mengutip beberapa hasil penelitian terdahulu yang menyatakan bahwa peer dan self assessment tidak dapat berhasil jika siswa merasa tidak mampu atau merasa tidak diberi pengarahan dengan baik, siswa merasa terbebani dengan sistem ini, dan jika pengajar maupun siswa bersikap subjektif dalam memberikan penilaian. Peer dan self assessment juga tidak dapat berjalan dengan efektif jika kriteria yang digunakan 
untuk melakukan peer dan self assessment tidak dapat dibuktikan validitas dan reliabilitasnya (Hancock, Dale-Jones, \& Willey, 2013).

Sebaliknya, jika siswa diberi pengarahan dan informasi yang sangat jelas tentang tujuan dan cara melakukan peer dan self assessment, maka sistem penilaian ini akan berjalan dengan sangat efektif. Selain itu, siswa juga perlu diberi penjelasan tentang manfaat peer dan self assessment bagi masa depan mereka, sehingga mereka semakin termotivasi untuk melakukan penilaian tersebut.

\section{METODE}

Penelitian ini merupakan penelitian deskriptif. Pengambilan data dilakukan selama empat tahun (2011 - 2015) dari peer dan self assessment yang dilakukan di kelas Analisis Laporan Keuangan UPH Surabaya selama enam semester. Terdapat enam angkatan mahasiswa yang menempuh mata kuliah Analisis Laporan Keuangan selama periode penelitian, yaitu angkatan 2008 sampai dengan angkatan 2013. Dengan demikian diharapkan dapat diketahui keakuratan peer assessment yang dilakukan selama ini.

\section{HASIL DAN PEMBAHASAN}

\section{Peer Assessment dan Self Assessment pada Program Studi Akuntansi UPH Surabaya}

Peer Assessment dan self assessment pada program studi akuntansi di UPH Surabaya telah dilakukan selama beberapa tahun dan dalam beberapa mata kuliah. Kegiatan ini dilakukan salah satunya untuk menilai final project yang harus dibuat mahasiswa. Dalam final project tersebut, mahasiswa diminta untuk melakukan analisis terhadap laporan keuangan perusahaan selama tiga tahun berturut-turut. Setelah melakukan analisis, mahasiswa diminta untuk melakukan wawancara terhadap minimal dua orang praktisi yang dalam kesehariannya melakukan analisis terhadap laporan keuangan perusahaan. Tujuan dari wawancara tersebut adalah untuk memperoleh pendapat dari praktisi tentang kondisi keuangan perusahaan yang dianalisis. Pendapat praktisi tersebut dapat memperkuat ataupun menyanggah analisis yang telah dilakukan mahasiswa. Di bagian penutup, mahasiswa akan membuat kesimpulan dan rekomendasi bagi pihak-pihak yang terkait.

Pada saat awal perkuliahan, siswa diberi penjelasan tentang silabus, tujuan perkuliahan, termasuk juga tentang final project yang harus dikerjakan. Hal ini sesuai dengan teori yang disampaikan oleh Reese-Durham (2005). Selama proses perkuliahan, para siswa diberi penjelasan tentang cara penilaian dengan menggunakan peer dan self assessment. Selain itu para siswa juga diperkenalkan dengan rubrik penilaian yang digunakan. Sebelum melakukan 
Peer dan self assessment pada final project, para siswa berlatih untuk melakukan Peer dan self assessment dalam tugas mingguan yang juga harus mereka buat. Dengan demikian diharapkan pada saat melakukan penilaian final project, para siswa telah cukup familiar dengan cara penilaian ini yang berdampak pada objektivitas nilai yang mereka berikan (Thomas, Martin, \& Pleasant, 2011).

Hasil Peer dan self assessment yang dilakukan ternyata tidak berbeda jauh dengan penilaian yang diberikan oleh dosen. Selain itu, setiap siswa cenderung memberikan bobot nilai yang sama. Sebagai contoh, jika ada satu siswa yang menonjol, setiap siswa yang lain cenderung memberikan penilaian yang tinggi pada siswa tersebut. Sebaliknya, jika ada seorang siswa yang kinerjanya kurang bagus, teman-teman sekelasnya cenderung memberikan nilai yang relatif sama untuk siswa tersebut. Hal ini juga berlaku pada siswa itu sendiri. Jika ia merasa bahwa kinerjanya kurang dibanding dengan teman-temannya, ia cenderung memberikan penilaian yang lebih rendah untuk dirinya sendiri dibandingkan dengan nilai teman-temannya.

Hasil penelitian ini sesuai dengan teori yang disampaikan oleh Hancock, Dale-Jones, \& Willey (2013) dan Thomas, Martin, \& Pleasant (2011). Kedua peneliti terdahulu tersebut menyatakan bahwa hasil peer dan self assessment akan efektif jika sebelum melakukan penilaian, para siswa diberi penjelasan terlebih dahulu sehingga siswa mengerti dengan jelas dan tidak merasa terbebani dengan apa yang harus mereka lakukan. Hasil penelitian ini sekaligus mematahkan ketakutan yang diungkapkan oleh Kennedy dalam Rochmiyati (2013), Karami \& Rezaei (2015) dan Landry, Jacobs, \& Newton (2015) yang menyatakan bahwa ada potensi ketidak-konsistenan siswa dalam melakukan penilaian.

\section{SIMPULAN}

Peer dan self assessment merupakan metode penilaian yang melibatkan partisipasi aktif dari siswa. Dengan metode ini, para siswa dapat melatih kemampuan analisis, interpretasi dan mengkomunikasikan hasil pemikirannya. Peer dan self assessment dapat berjalan dengan baik apabila penjelasan lengkap diberikan sebelum penilaian dilakukan sehingga mahasiswa tidak merasa terbebani dengan apa yang harus mereka lakukan. Hal ini telah terbukti dalam peer dan self assessment yang dilakukan di program studi akuntansi UPH Surabaya.

\section{DAFTAR RUJUKAN}

Accounting Education Change Commission. (1990). Position statement no. 1, objectives of education for accountants. Issues in Accounting Education, 5 (2), 307-312. 
Birjandi, P., \& Siyyari, M. (2010). Self-assessment and peer-assessment: A comparative study of their effect on writing performance and rating accuracy. Iranian Journal of Applied Linguistics, 13(1), 23-45.

Chaney, B. A., \& Ingraham, L. R. (2009). Using peer grading and proofreading to ratchet student expectations in preparing accounting cases. American Journal of Business Education, 2(3), 39-48.

Falchikov, N., \& Goldfinch, J. (2000). Student Peer assessment in higher education : a meta analysis comparing peer and teacher marks. Review of Educational Research, 287-322.

Hancock, P., Dale-Jones, G., \& Willey, K. (2013). Impact of collaborative peer and self assessment on students' judgment and written communication. Teaching \& Learning Forum, 1-12.

Hirsch, M. L. \& Gabriel, S. L. (1995). Feedback strategies: Critique and evaluation of oral and written assignments. Journal of Accounting Education, 13(3), 259-279.

Karami, A., \& Rezaei, A. (2015). An overview of peer-assessment: The benefits and importance. Journal for the Study of English Linguistics , 3 (1), 93-100

Kerby, D. (2008). The use of peer review to develop writing skills in an introduction to accounting class. Accounting Instructur Report.

Landry, A., Jacobs, S., \& Newton, G. (2015). Effective use of peer assessment in a graduate level writing assignment: A case study. International Journal of Higher Education, 4 (1), 38-52

Reese-Durham, N. (2005). Peer evaluation as an active learning technique. Journal of Instructional Technology, 32, 338-346

Rochmiyati. (2013). Model peer assessment pada pembelajaran kolaboratif elaborasi IPS terpadu di sekolah menengah pertama. Jurnal Penelitian dan Evaluasi Pendidikan, 17 (2), 333-346.

Siswaningsih, W., Dwiyanti, G., \& Gumilar, C. (2013). Penerapan peer assessment dan self assessment pada tes formatif hidrokarbon untuk feedback siswa SMA kelas X. Jurusan Pendidikan Kimia FPMIPA, 18(1), 107-115.

Thomas, G., Martin, D., \& Pleasant, K. (2011). Using self- and peer-assessment to enhance students' future-learning in higher education. Journal of University Teaching \& Learning Practice, 8(1), 1-17.

Topping, K. (1998). Peer assessment between students in colleges and universities. Review of Educational Research, 68(3), 249-276.

Willey, K. \& Freeman, M. (2006). Improving teamwork and engagement: The case for self and peer assessment. Australasian Journal of Engineering Education. http://www.aaee.com.au/journal/2006/willey0106.pdf 